\title{
Gastrointestinal helminths in calves and cows in an organic milk production system
}

Helmintos gastrintestinais em bezerros e vacas em sistema orgânico de produção de leite

Jenevaldo Barbosa da Silva ${ }^{1}$; Charles Passos Rangel ${ }^{2}$;

Adivaldo Henrique da Fonseca ${ }^{2 *}$; João Paulo Guimarães Soares ${ }^{3}$

${ }^{1}$ Faculdade de Ciências Agrárias e Veterinárias - UNESP, Jaboticabal, SP, Brasil

${ }^{2}$ Pós-graduaçáo em Ciências Veterinárias, Universidade Federal Rural do Rio de Janeiro - UFRRJ, Seropédica, RJ, Brasil

${ }^{3}$ Empresa Brasileira de Pesquisa Agropecuária - Embrapa Cerrados, Planaltina, DF, Brasil

Received April 4, 2011

Accepted January 20, 2012

\begin{abstract}
The main aim of this study was to determine the distribution of populations of gastrointestinal helminths in lactating crossbred cows and calves during the grazing season in an organic milk production system. In addition, the potential importance of the peripartum in relation to the parasite load was examined. Between January 2007 and December 2008, parasitological fecal examinations were performed on cattle belonging to the Integrated Animal Production Program of Embrapa Agrobiology. The cows' parasite load remained low during the study period, and there were no statistical differences $(\mathrm{p}>0.05)$ in comparisons between the seasons. The average egg count showed a positive correlation (0.80) with the peripartum, such that egg elimination per gram $(\mathrm{p}<0.05)$ was higher during the week of labor than during the pre and postpartum periods. Calves showed low parasite loads, with significantly higher egg elimination $(\mathrm{p}<0.05)$ during the winter. The study indicated that infection with gastrointestinal helminths was not a limiting factor for milk production in the organic system. Specifically, it was concluded that the nematode load can be maintained at moderate levels throughout the production system, even in the absence of anthelmintic treatment.
\end{abstract}

Keywords: Pasture management, peripartum, sustainable production.

\section{Resumo}

Os objetivos do estudo foram conhecer a distribuição das populaçóes de helmintos gastrintestinais de vacas mestiças em lactaçáo e bezerros, durante a primeira estação de pastejo em sistema de manejo orgânico, além de avaliar a importância do periparto na carga parasitária dos animais. No período de janeiro de 2007 a dezembro de 2008, foram realizados exames coproparasitológicos no rebanho bovino pertencente ao Sistema Integrado de Produção Animal, Embrapa Agrobiologia. A carga parasitária das vacas permaneceu baixa durante o período estudado, náo sendo observada diferença estatística ( $\mathrm{p}>0,05)$, assim como quando comparadas as estaçôes do ano. Os valores médios da contagem de ovos apresentaram correlaçáo positiva $(0,80)$ com o periparto, sendo observada, na semana do parto, significativa $(\mathrm{p}<0,05)$ eliminaçáo de ovos por grama de fezes superior ao pré e pós-parto. Os bezerros apresentaram baixa carga parasitária, com eliminaçáo de ovos significativamente maior $(\mathrm{p}<0,05)$ durante o inverno. $\mathrm{O}$ estudo indicou que a infecção por helmintos gastrintestinais não constitui fator limitante ao sistema de produção orgânica de leite. A carga de nematóides pode ser mantida em níveis moderados por meio do manejo, mesmo na ausência de tratamentos anti-helmínticos.

Palavras-chave: Manejo de pastagens, periparto, produçấo sustentável.

\section{Introduction}

The organic food market has a turnover of approximately six billion dollars a year in the United States (US), despite representing less than $1 \%$ of the total food consumption in that

\footnotetext{
*Corresponding author: Adivaldo Henrique da Fonseca

Departamento de Epidemiologia e Saúde Pública, Universidade Federal Rural do Rio de Janeiro - UFRRJ, BR 465, Km 07, CEP 23890-000, Seropédica, RJ, Brasil e-mail: adivaldo@ufrrj.br
}

country. Despite this small market share, the consumption of organic products has been growing annually by $20-30 \%$ in the US (THAMSBORG, 2001) and 30-40\% in the United Kingdom (WELLER; BOWLING, 2000).

Over $25 \%$ of total sales of dairy products in Sweden are of organic origin (BUSATO et al., 2000). Both in the US and in the European Union (EU), sustainable production systems are being 
increasingly recognized by governments as a tool for improving the diversity and stability of rural incomes.

In Brazil, interest in organic products is growing at a rate of about $10 \%$ a year, which reflects consumption of products from animals raised in systems that promote animal welfare and are sustainable and environmentally friendly (D'ALMEIDA, 2005). Despite great potential for development of this sector, this country still has negligible production.

The first description of intestinal parasites in organic production systems was given by Thamsborg et al. (1999). Helminths have been considered to represent the greatest cause of economic losses relating to organic cattle (KANEENE; MILLER, 1992). These losses have been exacerbated by the prohibition of anthelmintic treatment among such animals (BRASIL, 2011). Consequently, the prevalence of gastrointestinal nematodes in organically farmed animals tends to be higher than in conventional dairy herds.

Nematode control in Brazilian cattle is based on prophylactic and therapeutic use of anthelmintics. However, because of the emergence of resistance and the presence of residues in meat and milk, it has become necessary to develop alternative control methods (OLIVEIRA et al., 2009). Among these methods is the use of parasitological techniques to identify susceptible animals and thus allow selective application of anthelmintics or even replacement of such susceptible animals within a herd (VERCRUYSSE et al., 2009).

Information relating to populations of nematodes in dairy cows and calves kept in organic production systems is scarce. Clearly, investigations on this topic are very important in order to clarify the epidemiology of these parasites in such systems (HÖGLUND et al., 2010). Thus, the objectives of the current study were to determine the distribution of populations of gastrointestinal helminths in lactating crossbred cows and calves, kept in an organic management system, during the first grazing season and to evaluate the potential impact of the peripartum on the parasite load.

\section{Material and Methods}

This study was conducted between January 2007 and December 2008, on an agroecological farm within the Integrated System for Organic Production, as a collaboration between the Brazilian Agricultural Research Corporation (Embrapa), the Federal Rural University of Rio de Janeiro (UFRRJ) and the Agricultural Research Corporation of the State of Rio de Janeiro (Pesagro-Rio). The experimental area was located in the municipality of Seropédica, state of Rio de Janeiro, in the microregion of Itaguaí (latitude $22^{\circ} 45^{\prime} \mathrm{S}$ and longitude $43^{\circ} 41^{\prime} \mathrm{W}$ and altitude $33 \mathrm{~m}$ ).

Two experiments were conducted simultaneously. In the first study, 23 cows were used. They were between three to nine years of age and were crossbred (Bos taurus $\times$ Bos indicus) with a blood level of between $1 / 2$ and 7/8 Holstein. In order to monitor the seasonal distribution of gastrointestinal helminths, fecal samples were collected every 15 days. In order to evaluate the relevance of the peripartum on the parasite load, 42 occurrences of labor were assessed. Fecal samples were collected every seven days during the four weeks pre-labor, during the week of labor and also during the first four weeks postpartum. The animals were kept in 11 paddocks of approximately $7000 \mathrm{~m}^{2}$ each, consisting of Tanzania grass (Panicum maximum cv. Tanzania) in combination with Calopo (Calopogonium muconoides). Grazing rotation was used, with seven days of grazing, 42 days of rest and a stocking rate of two AU/ha. The animals were fed daily during the dry season with elephant grass (Pennisetum purpureum Schum cv. cameroongrass), Siratro (Macroptilium atropurpureum) and sugarcane (Saccharum spp.).

In the second experiment, 15 calves were examined every two weeks from birth until the first year of age. The animals were crossbred (Holstein $\times$ Zebu) with a blood level of $1 / 2$ to 5/8 Gyr. According to the recommendations for organic management under Normative Instruction (NI) 46 from the Ministry of Agriculture, Livestock and Supply, the calves remained with the cows during milking, until reaching three months of age (BRASIL, 2011). For food management during the first two months, the calves were kept at night in stalls in the barn, and during the day, they remained in an area composed of Coastcross grass (Cynodon dactylon (L.) Pers., Coastcross) subdivided into two paddocks of $60 \mathrm{~m}^{2}$, with alternation every five days. Between the ages of three and six months, the animals were kept in an area of 0.47 ha, consisting of African Star grass pasture (Cynodon nlemfuensis, Vanderyst) intercropped with Araque (Arachis pintoi), Desmodium (Desmodium ovalifolium) and Estilosantes (Stylosanthes guianensis), divided into four paddocks of $1175 \mathrm{~m}^{2}$, in rotation with eight days of grazing and 42 days of rest. Once the calves reached seven months of age, they were introduced into the rest of the herd in an area of 7.8 ha divided into six paddocks of 1.3 ha each, consisting of Guinea grass (Panicum maximum cv. Tanzania) in combination with Calopo (mucunoides). Grazing rotation was used with seven days of grazing, 42 days of rest and a stocking rate of two AU/ha. During the dry season, supplementation with hay and Gliricidia (Gliricidia sepium) was provided for animals up to six months of age, and sugar cane (Saccharum officinarum) in association with pigeon pea (Cajanus cajan), elephant grass (Pennisetum purpureum, Schum cv cameroongrass) and Siratro (Macroptilium atropurpureum) for the older calves.

Fecal analyses were performed at the Parasitic Diseases Laboratory, Department of Epidemiology and Public Health, Veterinary Institute, UFRRJ. The egg count per gram of feces (EPG) and the recovery and identification of infective larvae were performed in accordance with the McMaster modified technique described by Ueno and Gonçalves (1998).

For statistical analysis, the EPG data were initially transformed into $\log _{10}(x+1)$ in order to normalize them. To investigate the influence of the variables as risk factors for occurrences of gastrointestinal nematodes in dairy cows, the average EPG values observed were initially subjected to the Spearman test to investigate whether there was any association between them. For quantitative assessment of different parameters, analysis of variance (ANOVA) was used, along with the Student t test at $5 \%$ significance, and also linear regression. The operating procedures were performed using the Epi Info statistical software version 3.3.2 (CENTERS FOR DISEASE CONTROL AND PREVENTION, 2005). 


\section{Results}

The average values and standard deviations of the helminth egg counts in the feces from cows between January 2007 and December 2008 are shown in Figure 1. There were no significant differences ( $p>0.05)$ in average fecal egg count values over the two years, or among the four seasons. It was observed that despite the fact that the animals had not received anthelmintic treatment, the egg counts remained low and did not exceed an average of 260 EPG.

In contrast, during the peripartum, there were significant differences $(p<0.05)$ in the average eggs counts between the pre-partum, calving and postpartum periods (Figure 2). Specifically, gastrointestinal nematode egg elimination was significantly higher $(\mathrm{p}<0.05)$ during the week of labor, than in the pre and postpartum samples. The fecal egg count was positively correlated (0.80) with the peripartum, thus highlighting the importance of relaxation of immunity in relation to the quantity of helminths detected.

Although the calves had been kept on pasture during their first year of life, the parasite load was continually low (Figure 3). However, egg elimination in feces was significantly higher $(\mathrm{p}<0.05)$ during the winter.

The maximum, median and minimum egg counts in feces from calves according to age are shown in Figure 4. During the first grazing season, there were no significant differences $(p>0.05)$ in worm loads between the three groups of animals. The rotational grazing and animal stocking in paddocks (according to age) resulted in the young animals having lower exposure to pastures infested with larvae released from adult animals, especially during the peripartum period. The low parasite load to which the calves were exposed appeared to have contributed towards development of the immune system and consequent absence of clinical cases of parasitic infections.

The results from fecal culture showed that Haemonchus (74.5\%), Trichostrongylus (22\%), Oesophagostomum (3\%) and Cooperia $(0.5 \%)$ were present. During the peripartum, there was no statistical difference $(p>0.05)$ in terms of the composition of the populations of gastrointestinal parasites. The comparison between the seasons demonstrated that, in the dry season, the quantity of Haemonchus larvae decreased significantly ( $\mathrm{p}>0.05$ ), relative to Trichostrongylus.

\section{Discussion}

The results observed in this study corroborate the findings of Höglund et al. (2001), who assessed dairy cows on organic farms in Sweden and discovered that the animals had levels of infection varying from mild to moderate.

Use of pasture management as an alternative to use of chemical products for controlling helminths has previously shown satisfactory results (THAMSBORG et al., 1999; ATHANASIADOU et al., 2002). In the present study, the animals were managed using a rotational grazing system with low stocking density, which was probably responsible for the low parasite load observed in the animals.

Another important factor to be considered relates to the degree of pureblood type. The herd was composed of crossbred animals (Holstein $\times$ Zebu), which are considered to be more resistant than

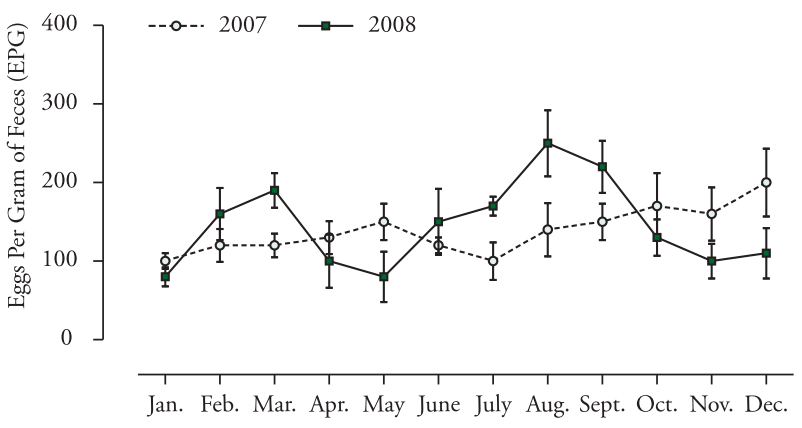

Figure 1. Average values and standard deviations of helminth egg counts in the feces of cows reared in an organic production system on an integrated livestock agroecological farm, Embrapa Agrobiology, 2007-2008.

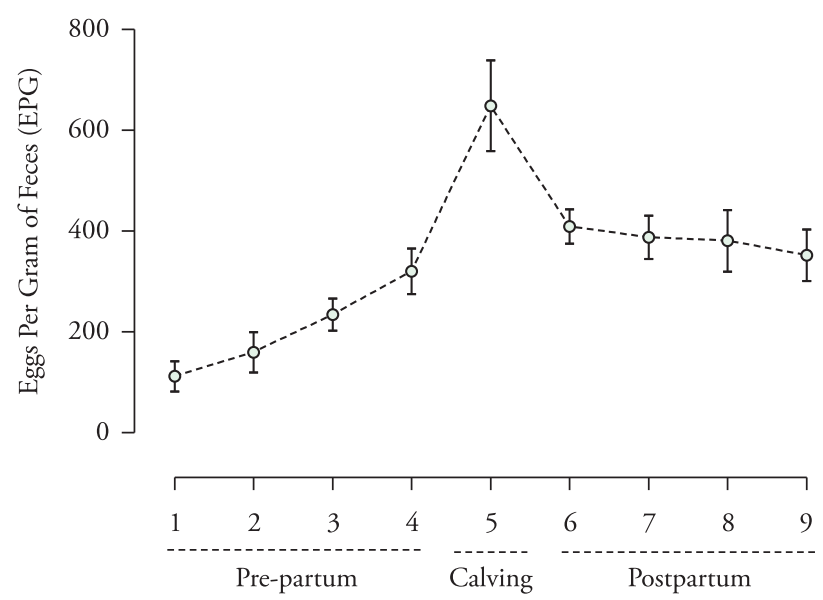

Figure 2. Average values and standard deviations of helminth egg counts in the feces of peripartum cows reared in an organic production system on an integrated livestock agroecological farm, Embrapa Agrobiology, 2007-2008.

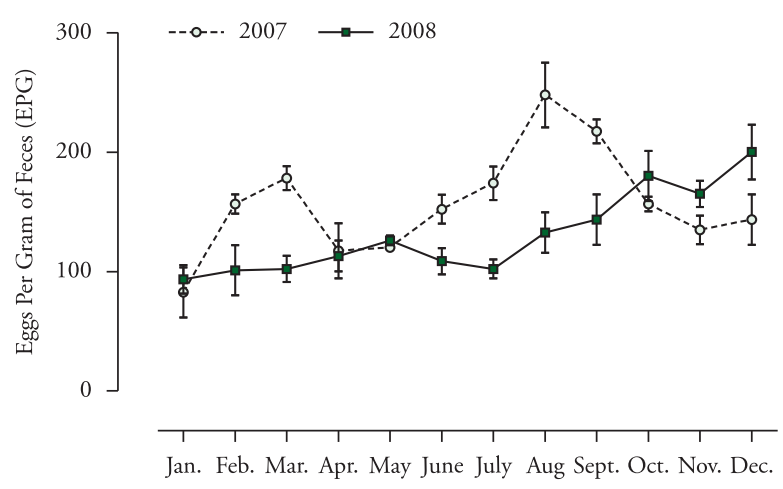

Figure 3. Average values and standard deviations of helminth egg counts in the feces of calves reared in an organic production system on an integrated livestock agroecological farm, Embrapa Agrobiology, 2007-2008. 


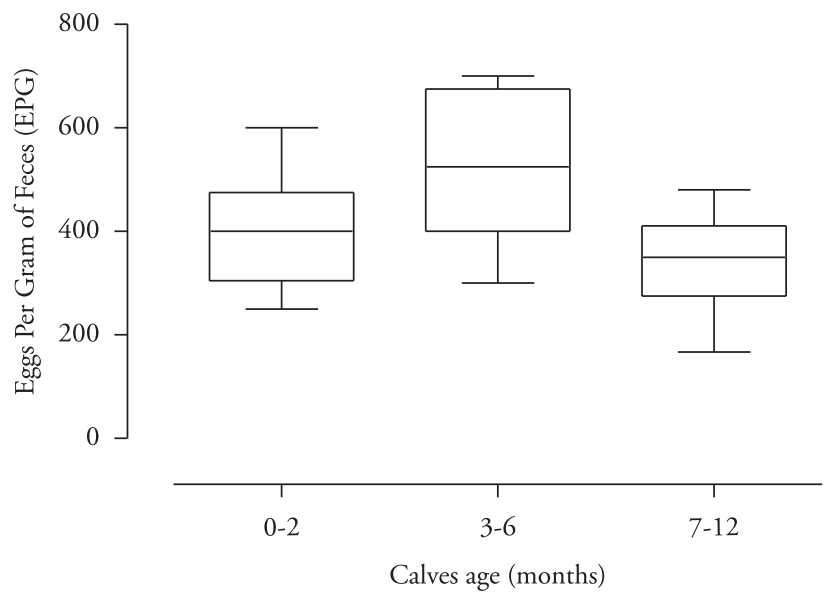

Figure 4. Maximum, median and minimum values of helminth egg counts in the feces of calves according to age, among calves kept in an organic production system on an integrated livestock agroecological farm, Embrapa Agrobiology, 2007-2008.

the Bos taurus breeds that are used in most conventional dairy farms. In this context, Oliveira et al. (2009) reported use of specific breeds as a means of controlling infection by gastrointestinal parasites in cattle in the tropics.

The peripartum period was identified as a risk factor by Lima (1998), who noticed average EPG values of between 100 and 200 and concluded that cows in the peripartum were the main source of both pasture contamination and infection of calves before weaning. Gennari et al. (2002) observed that a high level of nematode egg elimination occurred during the peripartum period in Holstein dairy cows. Moreover, Beasley et al. (2010) reported that close to the time of labor, there was a decrease in host immunity, as shown by high EPG counts and increased parasite levels in the host as a result of recent ingestion of infective larvae, or the presence of larvae that had matured with development.

The increase in egg elimination during the week of labor was probably not caused by maturation of larvae with hypobiosis, since none of the helminth species found accomplish this phenomenon in tropical regions (BEASLEY et al., 2010). Thus, the increased fecal egg count (FEC) during the peripartum may have been related to a recent intake of larvae coupled with possible immunosuppression among the animals. This may have provided an appropriate environment for proliferation of adult helminths, and may have contributed towards reducing the animals' defense against reinfection.

The significant increase in the quantity of nematode eggs in the week of delivery was not sufficient to cause clinical disease in adult animals, since they had previously acquired immunity against helminths.

The parasite loads in the calves in the present study were similar to those reported by Höglund et al. (2001) in Sweden, where low levels of egg elimination per gram of feces were observed in animals managed under an organic system during the first grazing season. In contrast, Vaarst et al. (2002) reported that there was a high degree of parasitism in grazing calves in Denmark during the first grazing season, and attributed their result to both the system used and the stocking rate. The low parasitic loads observed in the present study may be attributed to use of a rotational grazing system, as observed by Dimander et al. (2003). Pimentel Neto and Fonseca (2002) stated that in managing calves from three months of age onwards, it is necessary to be aware of worms, which can affect these animals up to the age of two years. The animals should receive special attention during this phase. Amarante et al. (1992) proved in their studies that helminths can affect cattle of all ages, although the effects are more severe in young animals. Although anthelmintics were not applied to the calves, the animals were kept in good quality pasture and received adequate supplementation during the seasonal food shortages. Athanasiadou et al. (2002) found that pasture management combined with nutritional supplementation during the dry season could be a sustainable solution for controlling helminth infections without using chemotherapy in grazing production systems.

Pimentel Neto and Fonseca (2002) studied populations of gastrointestinal helminths in calves and cows in the Municipality of Seropédica, RJ, over a number of years, and observed that Haemonchus predominated, followed by Trichostrongylus. The predominance of the genus Trichostrongylus during the dry season is related to the higher resistance of this worm to the environment during the more hostile seasons, which facilitates both survival and reinfection.

The low levels of parasitism observed in animals that had been kept in this organic system was considered satisfactory, given that the aim of the strategic control was to maintain low levels of infection and not to achieve complete eradication of the parasites (GASBARRE et al., 2001).

\section{Conclusions}

The distribution of populations of gastrointestinal helminths in dairy cows and calves in this organic production system did not constitute a health risk for the animals. However, the results suggest that even among well-managed adult cows, the week of labor is an important risk factor in the epidemiology of gastrointestinal nematode infections.

Measures such as rotational grazing, pasture rest periods, nutritional supplementation and use of genetically resistant animals are approaches that match with the principles of organic livestock production and play an important role in controlling gastrointestinal nematodes.

\section{Acknowledgements}

CNPq and FAPERJ for financial support. Embrapa Agrobiology and Pesagro-Rio for providing the animals for the study.

\section{References}

Amarante AFT, Barbosa MA, Oliveira M, Siqueira ER. Eliminação de ovos de nematódeos gastrointestinais por ovelhas de quatro raças durante diferentes fases reprodutivas. Pesq Agropec Bras 1992; 27(1): 47-51. 
Athanasiadou S, Arsenos G, Kyriazakis I. Animal health and welfare issues arising in organic ruminant production systems. In: Kyriazakis I, Zervas G. Organic meat and milk from ruminants. Netherlands: Wageningen Academic Publishers; 2002. p. 39-56.

Brasil. Ministério da Agricultura, Pecuária e Abastecimento. Instrução Normativa $\mathrm{n}^{\circ} 46$, de 6 de outubro de 2011. estabelece o Regulamento Técnico para os Sistemas Orgânicos de Produção Animal e Vegetal, bem como as listas de substâncias permitidas para uso nos Sistemas Orgânicos de Produção Animal e Vegetal. Diário Oficial da República Federativa do Brasil, Brasília, DF, 6 out. 2011. [cited 2012 fev 20]. Available from: http://sistemasweb.agricultura.gov.br/sislegis/action/detalhaAto.do?met hod=consultarLegislacaoFederal.

Beasley AM, Kahnb LP, Windon RG. The periparturient relaxation of immunity in Merino ewes infected with Trichostrongylus colubriformis: Endocrine and body compositional responses. Vet Parasitol 2010; 168(1-2): 51-59. PMid:20092949. http://dx.doi. org/10.1016/j.vetpar.2009.12.012

Busato A, Trachsel P, Schällibaum M, Blum JW. Udder health and risk factors for subclinical mastitis in organic dairy farms in Switzerland. Prev Vet Med 2000; 44(3-4): 205-220. http://dx.doi.org/10.1016/ S0167-5877(00)00104-5

Centers for Disease Control and Prevention. Epi Info. version 3.3.2. 2005. Database and statistics software for public health professionals. Available from: http://www.cdc.gov/epiinfo/downloads.htm.

D’Almeida TN. Bem-estar animal x segurança alimentar. Hig Aliment 2005; 19(132): 15-17.

Dimander SO, Höglund J, Uggla A, Spörndly E, Waller PJ. Evaluation of gastro-intestinal nematode parasite control strategies for first season grazing cattle in Sweden. Vet Parasitol 2003; 111(2-3): 193-209. http://dx.doi.org/10.1016/S0304-4017(02)00380-1

Gasbarre LC, Leighton EA, Sonstegard T. Role of the bovine immune system and genome in resistance to gastrointestinal nematodes. Vet Parasitol 2001; 98(1-3):51-64. http://dx.doi.org/10.1016/ S0304-4017(01)00423-X

Gennari SM, Blasques LS, Rodrigues AAR, Cilento MC, Souza SLP, Ferreira F. Determinaçáo da Contagem de Ovos de Nematódeos no Período Peri-parto em Vacas. BrazJ Vet Res Anim Sci 2002; 39(1):32-37.

Höglund J, Svensson C, Hessle A. A field survey on the status of internal parasites in calves on organic dairy farms in southwestern Sweden. Vet Parasitol 2001; 99(2):113-128. http://dx.doi.org/10.1016/ S0304-4017(01)00452-6
Höglund J, Dahlström F, Engström A, Hessle A, Jakubek EB, Schnieder $\mathrm{T}$, et al. Antibodies to major pasture borne helminth infections in bulk-tank milk samples from organic and nearby conventional dairy herds in south-central Sweden. Vet Parasitol 2010; 171(3-4):293-299. PMid:20466488. http://dx.doi.org/10.1016/j.vetpar.2010.04.002

Kaneene JB, Miller R. Description and evaluation of the influence of veterinary presence on the use of antibiotics and sulfonamides in dairy herds. Journal J Am Vet Med Assoc 1992; 201(1): 68-76.

Lima WS. Seasonal infection pattern of gastrointestinal nematodes of beef cattle in Minas Gerais State-Brazil. Vet Parasitol 1998; 74(2-4): 203-214. http://dx.doi.org/10.1016/S0304-4017(97)00164-7

Oliveira MC, Alencar MM, Chagas AC, Giglioti R, Oliveira HN. Gastrointestinal nematode infection in beef cattle of different genetic groups in Brazil. Vet Parasitol 2009; 166(3-4): 249-254. PMid:19828253. http://dx.doi.org/10.1016/j.vetpar.2009.09.006

Pimentel Neto M, Fonseca AH. Epidemiologia das helmintoses pulmonares e gastrintestinais de bezerros em regiáo de baixada do Estado do Rio de Janeiro. Pesq Vet Bras 2002; 22(4): 148-152. http://dx.doi. org/10.1590/S0100-736X2002000400004

Thamsborg SM, Roepstorff A, Larsen M. Integrated and biological control of parasites in organic and conventional production systems. Vet Parasitol 1999; 84(3-4): 169-186. http://dx.doi.org/10.1016/ S0304-4017(99)00035-7

Thamsborg SM. Organic farming in the Nordic countries - animal health and production. Acta Vet Scand 2001; 93(1): 7-15.

Ueno H, Gonçalves PC. Manual para diagnóstico das helmintoses de ruminante. Tókio: Japan International Cooperation Agency; 1998.

Vaarst M, Alban L, Mogensen L, Milan S, Thamsborg SM, Kristensen SE. Health and welfare in Danish dairy cattle during conversion to organic production: problems, priorities and perspectives. J Agric Environ Ethics 2002; 14(4):367-390. http://dx.doi. org/10.1023/A:1013060304868

Vercruysse J, Jackson F, Besier B, Pomroy B. Novel solutions for the sustainable control of nematodes in ruminants (PARASOL). Vet Parasitol 2009; 164(1): 1-2. PMid:19447549. http://dx.doi. org/10.1016/j.vetpar.2009.04.025

Weller RF, Bowling PJ. Health status of dairy herds in organic farming. Vet Rec 2000; 146(3): 80-81. PMid:10674698. http://dx.doi. org/10.1136/vr.146.3.80 